\title{
3D Technology for Children in Disadvantage Situations
}

\section{Tecnologia 3D para crianças desfavorecidas}

\author{
Margarida Pocinho*, Soraia Garcês*, Noemi Serrano-Diaz**, Marzanna Farnicka*** \\ *University of Madeira, Portugal, **University de Cadiz, Spain, ***University of Zielona Gora, Poland
}

\begin{abstract}
The world is under a process of globalization that implies an increase need of adaptation and 'survival'. Pre-school education as a setting that prepares children for their future needs to be side by side with it. Children in poverty lack many times opportunities to be in the centre of this development. Dream Makers project is a longitudinal study that aims to help pre-school children in disadvantage develop their creative, cognitive and technological skills. Through a social sciences methodology $3 \mathrm{D}$ technology is introduced. The ultimately goal is to develop a new model for curriculum education while promoting inclusion. Practical implications are discussed.
\end{abstract}

Keywords: 3D technology, creativity, multiple intelligences, dream makers.

\section{Resumo}

O mundo está sob um processo de globalização que implica a crescente necessidade de adaptação e 'sobrevivência'. A educação pré-escolar como um ambiente que prepara as crianças para o futuro necessita estar lado a lado com estas mudanças. Crianças pobres têm poucas oportunidades para estar no centro deste desenvolvimento. Dream Makers é um projeto longitudinal que objetiva ajudar crianças no pré-escolares socialmente desfavorecidas a desenvolver competências criativas, cognitivas e tecnológicas. Através de uma metodologia das ciências sociais a tecnologia 3D é introduzida. O objetivo último é desenvolver um modelo de currículo educativo, promovendo a inclusão social. Implicações práticas são discutidas.

Palavras chave: Tecnologia 3D, criatividade, inteligências múltiplas, dream makers.

Currently, the arrival of daily new technologies let us participate in the globalization process that takes place every day. The need to adapt and to apprehend these new technologies is a daily job. We are now more connected that ever before and more close socially, economically and culturally. Nevertheless, the evident proximity, simultaneously, differences are emphasized and, particularly, social differences leads to an uneven competition between individuals (Farnicka 2016a). The front-runners of this 'competition' are the ones with high status and/or power which means that those considered more fragile are often excluded. Inequality in society and particular its maintenance through generations can be due to different aspects. For example, this inequality may be beneficial for some (Gans, 1992), so maintaining it is desirable. But beyond social exclusion, social inclusion is a searched goal for government, countries and communities. Social inclusion means that individuals are considered one with the others in a common society. Identity and being treated as equal are fundamental and important to 'feel' being accepted. These processes are not static, they are flexible during our life span, being our own development important. But adaptation is a complex process that involves tolerance perceptions and acceptance (Pagani, 2014). Furthermore education and creativity can be the answer for the development of more inclusive societies (Farnicka, 2016).

It is important to give our children, from the very start tools to promote themselves social inclusion. The first stages of development in children early lives are fundamental in their growth. Directing a conscientious effort to promote social inclusion and develop children skills at these stages is fundamental for their future wellbeing and it can help in the decrease of expenses related to welfare, health, education and justice. Children who live in poor environments and where social exclusion may be a real problem are under risk. Consequently, poverty so early in life can lead to psychological, social, financial and much more damages in their development as future citizens (European AntiPoverty Network \& EUROCHILD, 2013). But additionally it can ultimately direct children lives to a decrease of belonging to social groups, underachievement in school, less wellbeing and a failure to see hope in their own future lives (Pocinho, 2010). It is a society necessity to help and provide for their children and this should be a top priority while encouraging their talents improvement (Diniz, Pocinho and Almeida, 2011; Pocinho, 2004, 2009a, 2010). This paper highlights the core components and guidelines of a new project "Dream Makers" that tries to promote children inner capabilities and social inclusion.

\section{Creativity, multiple intelligences and technology}

The idea of creativity is not new. For long society and communities have been acknowledging it, but it still is a complex construction. Two of the central features of creativity are novelty and usefulness. The first brings the idea of something new and the second that this new 'something' must be useful for someone, being it an individual or society. Creativity is an important piece for problem solving, however it is also related to divergent thinking skills, personality, cognition, motivation, 
imagination, culture and much more (Ferrari, Cachia, and Punie, 2009). These are crucial skills for education and particularly for the current time where 'the unknown' is the norm. Skinner (2007) argues that by experiencing creativity kids will developed their abilities of linking ideas, find solutions for problems, and develop their senses of beauty as also their self-esteem. An appropriate environment is fundamental for creative endeavours (Garcês, Pocinho, Jesus, and Viseu, 2016) and educational settings must have this in consideration when developing their curriculums.

Gardner Multiple Intelligences theory has been a theoretical framework that brought new ways of thinking children (and adults) talents and abilities. He presented the public with not one but eight intelligences and is currently studying a ninth. The first eight: Linguistic, Spatial, Logical/Mathematical, Interpersonal, Intrapersonal, Bodily-Kinesthetic, Musical and Naturalistic (Visser, Ashton, and Vernon, 2006; Pocinho, 2004) bring a different form to think about human beings diversity of abilities and the need to acknowledge that each and every one of us is different thus our intelligences also differ. In many occasions this theory is linked to creativity. We know that creativity is important and it can be crucial for children development in school environment including school success. It can also contribute to their psychological development (Garcês, Pocinho \& Jesus, 2013). By associating multiple intelligences and creativity we can bring together children strengths and give them the tools to a brighter future.

The arrival of new technologies is a constant nowadays. With the lightning speed of technological evolution, it is a must to education to prepare for it. 3D technology has arrived some time ago, but it is now suitable for its immersion in school curriculum. The few existing studies are already acknowledging that this new technology is linked to children motivation and facilitates their learning with real products and outcomes of their theoretical learning processes, bringing theory to practice (Szulzyk-Cieplak, Duda, and Sidor, 2014). As Canessa, Fonda and Zennaro (2013) stated 3D technology, sometimes called rapid prototyping, have printers that are machines that allow for the development of real objects. In simple terms, it starts with the need for model development digitally and then pass it on to the printer. An array of materials can be used such as plastic, wood, dust, metal, and many more. The reduction on costs and increase in usability has permitted its arrival to schools (Saorin et al., 2015). 3D technology has already been acknowledged as an evolving and building need for school settings from the EU and is expected to be more used in the coming years which reveals its significance to settings of education and also science (Johnson, Adams Becker, Estrada, and Freeman, 2013).

\section{The Project}

Dream Makers is the acronym for an Erasmus + KA2 project being developed by a three country partnership, namely: Portugal, Spain and Poland. The base conceptual elements for the Project are: creativity, multiple intelligences and 3D technology. It is in the association of these distinct but complementary variables that underlines the Project innovation, but also in its target population, children in economic disadvantage. Its aim is to develop in these children their creative, cognitive (in the Gardner intelligence perspective) and technological skills, but simultaneously promote inclusion and bilingualism. Its global and ambitious objective is to develop a new curriculum method to pre-school education where children abilities and technology are aligned to give them the best possible tools for their present and future development and persons and as future professionals.

\section{Methodology}

The project is under development at the moment. Starting at September 2016 it will end in August 2019. With emphasis in a social sciences methodology, particularly Psychology, it is a longitudinal experimental study, with pre and post-tests. The pilot school, a kindergarten, is in Portugal. It will next be implemented in Spain and Poland too. The activities that constitute the core project are what the partnership called "Creativity's Days". These are monthly activities where in each month of the school year a specific intelligence will be empathised by particular activities. At this activities it is also expected to develop and apply creative mind-sets. In these days activities centred on children learning of 3D software manipulation and posterior 3D printing are included, having in consideration age appropriate software. It is in the merging of social sciences and technology that we do believe that innovation is a key part of the project. Through developing children strengths and skills and allying them with the technology advancements we aim to give these children hope to their future, but also capabilities to cope and go beyond their current social and economic situations.

\section{Participants}

The project participants are children in economic disadvantage situations measured by their need of school social support. Their ages range from 4 to 6 years old. Since it is a longitudinal study it is expected that children will take part in the project through its whole duration. Ethics is a must in the project, so informed consents for the children participation was one of the very first concerns which were given to their legal guardians. Additionally, the partnership organizations will have training in each partner country to develop their personal and professional skills and learn about the core variables of the project and how they can apply it in education and particularly in their organizations.

\section{Evaluation}

The need to evaluate a project of this dimension is fundamental. The first battery of test was already applied and it is currently under qualitative and quantitative evaluation. The variables focus of evaluations are creativity, multiple intelligences and technology skills. However it is also important the analysis of the children academic achievement and also personal development. So three fundamental roots were taken. First children parents were given a questionnaire to fill where we aimed 
to understand their perception of their children skills. It was as also undertaken a semi-structured interview with them, to have a more in-depth comprehension of their opinions and perceptions. Similarly the children teachers were evaluated in the same manner as the parents, but having in consideration their own perception of their students' development and achievements. Finally, children were evaluated through psychological tests, such as Raven Progressive Matrices, and also through an interview age appropriate. Also observational grids are being filled through the observation of the Creativity Days.

\section{Final remarks}

The Dream Makers project is a new way to introduce technology in the classroom. Beyond this it is a new way of combining different fields of study with the goal of allowing or foster a better future life for children in need. 3D technology brings 'fresh air' to the education settings where paper and pencil are still the norm. The world is no longer like that. The world is digital nowadays and we must give our children the tools to deal with it. Despite the unknowing future we can at least prepare them with their own skills and promote in them the capacity to adapt and go beyond their ideas and put them into practice. This is the central point of the project and should also be the centre of today education, where also it is fundamental to promote a more inclusive society, giving opportunities to those who currently do not have them.

\section{Referencias}

Canessa, E., Fonda, C., \& Zennaro, M. (2013). Low-cost $3 D$ Printing for Science, Education \& Sustainable Development. Trieste, Italy: ICTP.

Diniz, A., Pocinho, M.D., and Almeida, L.S. 2011. Cognitive abilities, sociocultural background and academic achievement. Psicothema. 23(4): 695-700.

European Anti-Poverty Network \& EUROCHILD (2013).Towards Children's Well-Being in Europe: Explainer on Child Poverty in the EU. Acceded in $22^{\text {nd }}$ of March 2017, on the Web site of: European Parliament:

http://www.europarl.europa.eu/meetdocs/2014_2019/ documents/empl/dv/child_poverty_eurochild_/child_p overty_eurochild_en.pdf

Farnicka, M. (2016). Marginalization as Exclusion as a violence "in" society. Quicio Revista de Psicologia. 1 (1): 15-33.

Farnicka, M. (2016a). Social Mobility. In: C.L. Shehan, The Wiley Blackwell Encyclopedia of Family Studies. Wiley-Balckwell.

Ferrari, A., Cachia, R., and Punie, Y (2009). Innovation and Creativity in Education and Training in the EU Member States: Fostering Creative Learning and Supporting Innovative Teaching. Literature review on Innovation and Creativity in E\&T in the EU Member States. Acceded in 22 ${ }^{\text {nd }}$ of March 2017, on the Web site of: European Commission, Joint Research Centre, Institute for Prospective Technological Studies: http://ftp.jrc.es/EURdoc/JRC52374_TN.pdf
Gans, H. (1992). The war against the Poor - Report and Programm. In: M. L. Kennedy and W. J. Kennedy (eds.), A Reader and Rhetoric for Academic Writers. Pearson: Boston.

Garcês, S., Pocinho, M., and Jesus, S. (2013). Predição da Criatividade e da Saúde Mental. Psicologia, Saúde \& Doenças. 14 (2): 271-279.

Garcês, S., Pocinho, M., Jesus, S., and Viseu, J. (2016). The impact of creative environment on the creative person, process, and product. Revista Avaliação Psicológica. 15 (2): 169-176.

Johnson, L., Adams Becker, S., Cummins, M., Estrada, V., Freeman, A., and Ludgate, H. (2013). NMC Horizon Report: Edición sobre Educación Superior.

Pagani C. (2014). Violence as a complexity. In: C. Paganii, M. Farnicka , H. Liberska , J.M. Ramirez (eds.), Conflict and aggression: developmental and social conditions. Warszawa: Difin.

Pocinho, M. (2004). Psicologia cognitiva e língua materna: avaliação da eficácia dum programa de estratégias de aprendizagem para alunos com insucesso escolar em Língua Portuguesa. Ph.D. Thesis. University of Madeira.

Pocinho, M. (2009a). Enhancing Comprehension in Low Achieving 9th Graders: A quasi-experiment study. L1 - Educational Studies in Language and Literature. 9(4): 141-156.

Pocinho, M. (2010). Psicologia, cognição e sucesso escolar: concepção e validação dum programa de estratégias de aprendizagem. Psicologia: Reflexão $e$ Crítica. 23 (2): 362 - 373.

Saorin, J.L; De la Torre, J; Melian, D; Meier, C \& Rivero, D. (2015). Blokify: Juego de modelado e impresión 3D en tableta digital para el aprendizaje de vistas normalizadas y perspectiva. Digital Education Review. 27: 105-121.

Skinner, S. M. (2007). Creative activities for the early years. SAGE Publications Ltd. London. ISBN: 9781446214589

Szulzyk-Cieplak, J., Duda, A., and Sidor, B. (2014). 3D Printers - New Possibilities in Education. Advances in Science and Technology, 8 (24): 96-101.

Visser, B., Ashton, M., and Vernon, P. (2006). Beyond $g$ : Putting multiple intelligences theory to the test. Intelligence. 34: 487-502.

\section{Acknowledgement}

We thank the Erasmus+ Program, from European Union, which funds the Dream Makers Project. 